\title{
Dependence of Precipitation Behavior and Creep Strength on Cr Content in High $\mathrm{Cr}$ Ferritic Heat Resistant Steels*
}

\author{
Yoshinori MURATA**, Koji YAMASHITA***, Masahiko MORINAGA**, \\ Toru HARA****, Kazuhiro MIKI*****, Tsukasa AZUMA*****, \\ Toru ISHIGURO ${ }^{\dagger}$ and Ryokichi HASHIZUME ${ }^{\dagger \dagger}$ \\ **Graduate School of Engineering, Nagoya University, \\ Furo-cho, Chikusa, Nagoya 464-8603, Japan \\ E-mail:murata@numse.nagoya-u.ac.jp \\ *** Graduate Student, Nagoya University, \\ ${ }^{* * * *}$ National Institute for Materials Science (NIMS), \\ 1-2-1 Sengen, Tsukuba 305-0047, Japan \\ *****Muroran Research Laboratory, Japan Steel Works Ltd., \\ 4 Chatsu-cho, Muroran 051-6505, Japan \\ ${ }^{\dagger}$ Institute of Multidisciplinary Research for Advanced Materials, Tohoku University, \\ 2-1-1 Katahira, Aoba, Sendai 980-8577, Japan \\ ${ }^{\dagger \dagger}$ Power Engineering R\&D Center, The Kansai Electric Power Co. Inc., \\ 3-11-20 Nakoji, Amagasaki 661-0974, Japan
}

\begin{abstract}
It is known that high temperature tensile strength increases with increasing $\mathrm{Cr}$ content in Cr containing heat resistant steels. Recently, however, it was found that long-term creep strength decreased with increasing $\mathrm{Cr}$ content in the heat resistant steels containing $8.5-12 \% \mathrm{Cr}$. In this study, precipitation behavior of $\mathrm{M}_{23} \mathrm{C}_{6}$ carbide and the $\mathrm{Z}$ phase after creep tests was investigated using two kinds of high $\mathrm{Cr}$ ferritic steels $(9 \mathrm{Cr}$ and $10.5 \mathrm{Cr}$ ). As a result, $10.5 \mathrm{Cr}$ steel exhibited larger average particle size of $\mathrm{M}_{23} \mathrm{C}_{6}$ than $9 \mathrm{Cr}$ steel irrespective of creep stress levels, but the amount of $\mathrm{M}_{23} \mathrm{C}_{6}$ carbide was almost the same in both steels. On the other hand, the amount of the $\mathrm{Z}$ phase became large in $10.5 \mathrm{Cr}$ steel compared with $9 \mathrm{Cr}$ steel. These experimental results indicate that high level of $\mathrm{Cr}$ content accelerates precipitation and coalescence rate of both $\mathrm{M}_{23} \mathrm{C}_{6}$ carbide and the $\mathrm{Z}$ phase, resulting in degradation of long term creep strength in $10.5 \mathrm{Cr}$ steel compared to $9 \mathrm{Cr}$ steel.
\end{abstract}

Key words: Precipitation, $\mathrm{M}_{23} \mathrm{C}_{6}$ Carbide, $\mathrm{Z}$ Phase, Long Term Creep, High $\mathrm{Cr}$, Ferritic Steel

\section{Introduction}

It is known that high $\mathrm{Cr}$ heat resistant ferritic steels show the premature failure in creep rupture at $650^{\circ} \mathrm{C}$, i.e., the creep strength in a long time becomes lower than the expected values extrapolated from short time creep tests ${ }^{(1)}$. Recently, the dependence of this premature failure on $\mathrm{Cr}$ content in high $\mathrm{Cr}(8.5-12 \% \mathrm{Cr})$ ferritic steels has been investigated systematically and was reported that the rupture strength in the long time over $10000 \mathrm{~h}$ increased with decreasing $\mathrm{Cr}$ content in those high $\mathrm{Cr}$ ferritic steels ${ }^{(2,3)}$. As a result, $8.5 \% \mathrm{Cr}$ steel shows never premature failure even at $650^{\circ} \mathrm{C}$. The mechanism of the trade-off relationship between high temperature tensile strength and creep strength with respect to $\mathrm{Cr}$ content is still unknown.

In general, the long term creep strength of high $\mathrm{Cr}$ ferritic steels is known to be related 
closely to the microstructural evolution of them. The purpose of this study is to investigate microstructural evolution after creep tests in high $\mathrm{Cr}$ ferritic steels varying only the $\mathrm{Cr}$ content. In particular, this investigation is focused on the precipitation and coalescence behavior of $\mathrm{M}_{23} \mathrm{C}_{6}$ carbide and the $\mathrm{Z}$ phase, both of which contain a large amount of $\mathrm{Cr}$.

\section{Experimental Procedure}

Two kinds of steels varying only $\mathrm{Cr}$ content are used in this study. Their chemical compositions are listed in Table 1. Except for $\mathrm{Cr}$, all elements are similar to each other within an error, and these two steels contain $0.1 \mathrm{C}, 3 \mathrm{Co}, 3.5 \mathrm{~W}, \mathrm{~V}, \mathrm{Nb}, \mathrm{Mo}, \mathrm{B}$ and $\mathrm{N}$. $\mathrm{Cr}$ contents of these steels are $9.0 \%$ and $10.5 \%$. Hereafter, they are called as $9 \mathrm{Cr}$ steel and $10.5 \mathrm{Cr}$ steel, respectively. A typical result on creep rupture tests reported so far in both steels is shown in Fig. ${ }^{(2,3)}$, and it was found that $10.5 \mathrm{Cr}$ steel showed a premature failure at $650^{\circ} \mathrm{C}$ in a long time compared to $9 \mathrm{Cr}$ steel.

Table 1 Chemical compositions of the experimental steels used. (mass\%)

\begin{tabular}{|c|c|c|c|c|c|c|c|c|c|c|c|c|}
\hline Steel & $\mathrm{C}$ & $\mathrm{Si}$ & $\mathrm{Mn}$ & $\mathrm{Ni}$ & $\mathrm{Cr}$ & $\mathrm{Mo}$ & $\mathrm{V}$ & $\mathrm{Nb}$ & $\mathrm{W}$ & $\mathrm{Co}$ & $\mathrm{B}$ & $\mathrm{N}$ \\
\hline $\begin{array}{c}9 \mathrm{Cr} \\
\text { Steel }\end{array}$ & 0.09 & 0.03 & 0.01 & 0.21 & $\mathbf{9 . 0}$ & 0.11 & 0.15 & 0.06 & 3.6 & 3.0 & 0.009 & 0.020 \\
\hline $\begin{array}{c}10.5 \mathrm{Cr} \\
\text { Steel }\end{array}$ & 0.10 & 0.03 & 0.01 & 0.20 & 10.5 & 0.10 & 0.15 & 0.06 & 3.5 & 3.0 & 0.010 & 0.021 \\
\hline
\end{tabular}

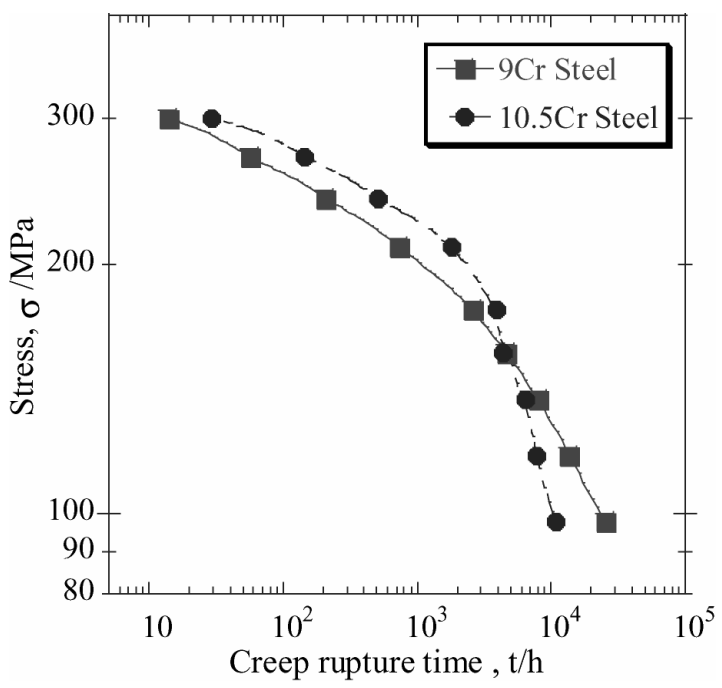

Fig.1 Time to rupture curves of $9 \mathrm{Cr}$ and $10.5 \mathrm{Cr}$ steels at $650^{\circ} \mathrm{C}$

Extraction replicas were prepared from the steels crept or simple aged specimens at $650^{\circ} \mathrm{C}$. Precipitates on the replica were analyzed with STEM/EDX and were classified as MX carbonitride, $\mathrm{M}_{23} \mathrm{C}_{6}$ carbide, the Laves phase or the $\mathrm{Z}$ phase on the basis of the amounts of $\mathrm{Cr}, \mathrm{V}, \mathrm{Nb}, \mathrm{W}$ and $\mathrm{Fe}$ in each precipitate, i.e., almost all metallic element in $\mathrm{MX}$ carbonitride is $\mathrm{V}$ or $\mathrm{Nb}, \mathrm{M}_{23} \mathrm{C}_{6}$ carbide is $\mathrm{Cr}$, whereas the Laves phase shows $(\mathrm{Fe}, \mathrm{Cr})_{2} \mathrm{~W}$ type concentration ratio and the $\mathrm{Z}$ phase contains both $\mathrm{Cr}$ and $\mathrm{V}^{(4)}$, as mentioned below.

On the basis of STEM/EDX data taken from a series of the specimens, the sizes of $\mathrm{M}_{23} \mathrm{C}_{6}$ carbide and the $\mathrm{Z}$ phase were obtained by means of image analysis and also the volume fraction of them was measured with the area analyzing method ${ }^{(5)}$. From these measured data, change in the size with annealing time was obtained. 


\section{Experimental Results and Discussion}

TEM microstructures of $9 \mathrm{Cr}$ and $10.5 \mathrm{Cr}$ steels as tempered state are shown in Fig.2. The both microstructures are almost the same and show the lath martensite structure containing fine precipitates of the Laves phase ${ }^{(6)}$ together with granular $\mathrm{M}_{23} \mathrm{C}_{6}$ carbide. In crept specimens, besides these precipitates, the $\mathrm{Z}$ phase was observed. Typical EDX data taken from $\mathrm{M}_{23} \mathrm{C}_{6}$ carbide and the $\mathrm{Z}$ phase is shown in Fig.3. $\mathrm{M}_{23} \mathrm{C}_{6}$ carbide consists mainly of $\mathrm{Cr}$ and contains $\mathrm{Fe}$ together with a small amount of Mo and $\mathrm{W}$, whereas the $\mathrm{Z}$ phase contains about $50 \% \mathrm{Cr}, 20 \% \mathrm{~V}$ and several $\%$ of $\mathrm{Nb}$. Thus, the $\mathrm{Z}$ phase can be distinguished from $\mathrm{M}_{23} \mathrm{C}_{6}$ carbide and the Laves phase $\left(\mathrm{Fe}_{2}(\mathrm{Mo}, \mathrm{W})\right)$. Volume fractions of $\mathrm{M}_{23} \mathrm{C}_{6}$ carbide and the $\mathrm{Z}$ phase in $9 \mathrm{Cr}$ and $10.5 \mathrm{Cr}$ steels annealed at $650^{\circ} \mathrm{C}$ without stress (grip portion of the crept specimens) are shown in Fig.4. In this figure, the equilibrium volume fraction of each phase, which is calculated by using the Thermo-Calc, is also shown as an arrow in the right hand side. It is found that the amount of $\mathrm{M}_{23} \mathrm{C}_{6}$ carbide exhibits a constant level irrespective to the annealing time and it is almost the same as the equilibrium value in each steel. This fact indicates that $\mathrm{M}_{23} \mathrm{C}_{6}$ carbide becomes nearly the equilibrium state even in the tempered state.
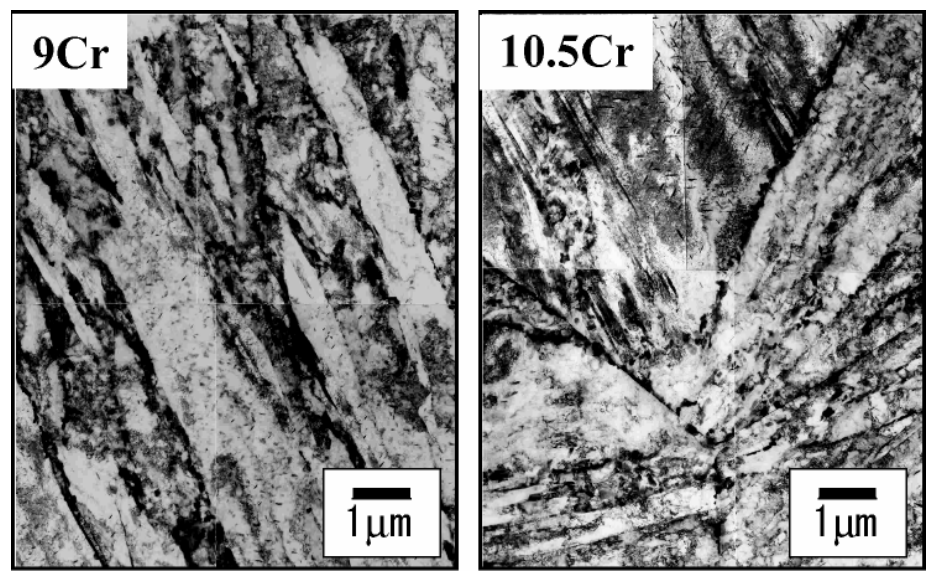

Fig.2 TEM microstructures of $9 \mathrm{Cr}$ and $10.5 \mathrm{Cr}$ steels as tempered state

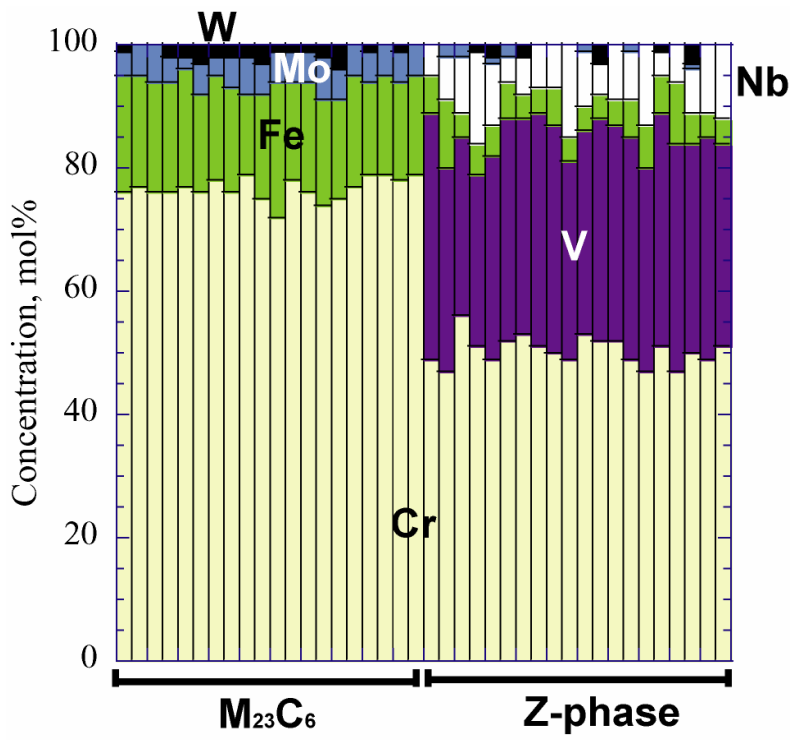

Fig.3 Typical EDX data taken from $\mathrm{M}_{23} \mathrm{C}_{6}$ carbide and the $\mathrm{Z}$ phase on the extraction replica 
The $\mathrm{Z}$ phase is observed remarkably in $10.5 \mathrm{Cr}$ steel annealed over $5000 \mathrm{~h}$ but is scarcely observed in $9 \mathrm{Cr}$ steel, in which the $\mathrm{Z}$ phase is found a little after more than $25000 \mathrm{~h}$ annealing, as shown in open square marks in Fig.4 . The amount of the $\mathrm{Z}$ phase becomes a constant value in $10.5 \mathrm{Cr}$ steel after $10000 \mathrm{~h}$ annealing and this value is similar to the calculated equilibrium one, whereas the amount of the $\mathrm{Z}$ phase in $9 \mathrm{Cr}$ steel after $30000 \mathrm{~h}$ annealing is still lower than the equilibrium value. These results are direct evidence that the $\mathrm{Z}$ phase form easily in high $\mathrm{Cr}$ steels compared to low $\mathrm{Cr}$ steels.

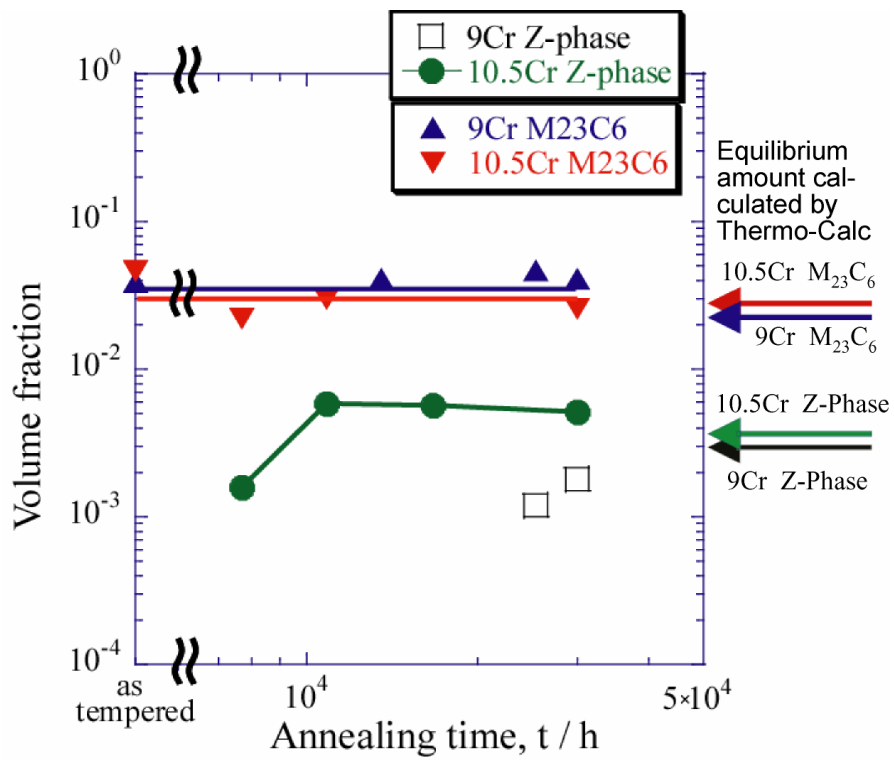

Fig.4 Volume fractions of $\mathrm{M}_{23} \mathrm{C}_{6}$ carbide and the $\mathrm{Z}$ phase in $9 \mathrm{Cr}$ and $10.5 \mathrm{Cr}$ steels annealed at $650^{\circ} \mathrm{C}$ without stress

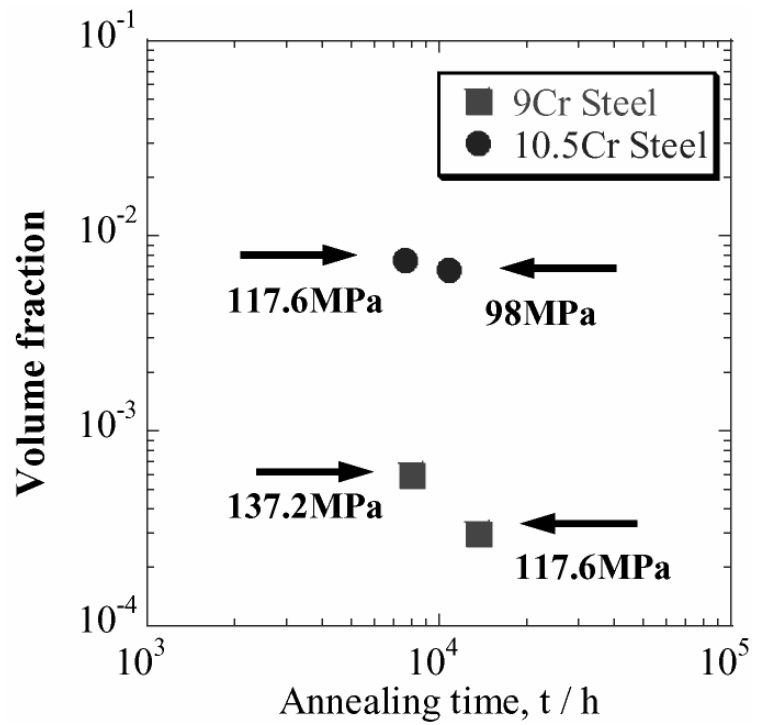

Fig.5 Volume fraction of the Z-phase obtained from the gauge parts of $9 \mathrm{Cr}$ and $10.5 \mathrm{Cr}$ steels both after creep tests at $650^{\circ} \mathrm{C}$.

Figure 5 shows a plot of the volume fraction of the $\mathrm{Z}$ phase obtained from the gauge portion in crept specimens of $9 \mathrm{Cr}$ and $10.5 \mathrm{Cr}$ steels against the rupture time (corresponding to the annealing time) at $650^{\circ} \mathrm{C}$ with several stress levels. In the gauge portion, trend of 
the $\mathrm{Z}$ phase precipitation is similar to that in the grip parts, i.e., $10.5 \mathrm{Cr}$ steels shows much larger amount of the $\mathrm{Z}$ phase than $9 \mathrm{Cr}$ steel. Here, it can be observed that the volume fraction of the $Z$ phase depends on stress levels and it becomes high in the specimen undergone high stress condition irrespective of $\mathrm{Cr}$ content in the steels. This fact indicates that creep stress accelerates the $\mathrm{Z}$ phase formation in high $\mathrm{Cr}$ ferritic steels.

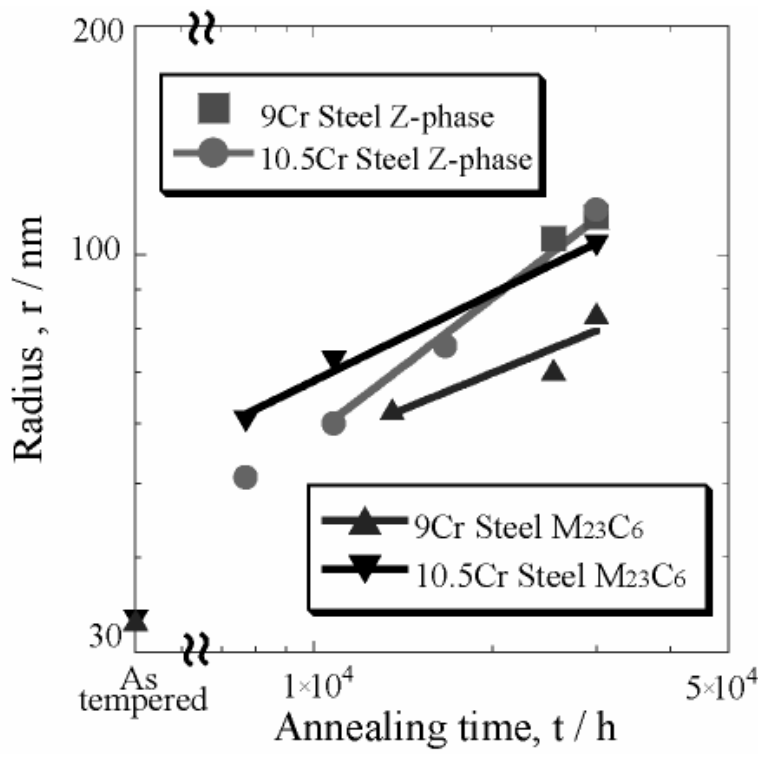

Fig.6 Change in the radius of both $\mathrm{M}_{23} \mathrm{C}_{6}$ carbide and the Z-phase with annealing time in both $9 \mathrm{Cr}$ and $10.5 \mathrm{Cr}$ steels annealed at $650^{\circ} \mathrm{C}$

Figure 6 shows the change in radius of both $\mathrm{M}_{23} \mathrm{C}_{6}$ carbide and the $\mathrm{Z}$ phase with annealing time in both $9 \mathrm{Cr}$ and $10.5 \mathrm{Cr}$ steels annealed at $650^{\circ} \mathrm{C}$ without any stress. Straight lines in this figure are obtained from the regression analysis using the data corresponding to the constant volume fractions of both $\mathrm{M}_{23} \mathrm{C}_{6}$ carbide and the $\mathrm{Z}$ phase, as shown in Fig.4. Thus the data on the $\mathrm{Z}$ phase obtained in $10.5 \mathrm{Cr}$ steel annealed for $5000 \mathrm{~h}$ is omitted from the regression analysis. The coalescence rate of $\mathrm{M}_{23} \mathrm{C}_{6}$ carbide exhibits no difference between the two steels and it depends on $\mathrm{t}^{1 / 3}$ of annealing time, indicating that the rate controlling process of $\mathrm{M}_{23} \mathrm{C}_{6}$ carbide is atomic diffusion. Although the coalescence rate is the same in the two steels, the size of $\mathrm{M}_{23} \mathrm{C}_{6}$ carbide in $10.5 \mathrm{Cr}$ steel is much larger than that in $9 \mathrm{Cr}$ steel. For example, the size is about 73 and $100 \mu \mathrm{m}$ at $1 \times 10^{4} \mathrm{~h}$ and $3 \times 10^{4} \mathrm{~h}$, respectively, in $10.5 \mathrm{Cr}$ steel and about 60 and $80 \mu \mathrm{m}$ at $1.3 \times 10^{4} \mathrm{~h}$ and $3 \times 10^{4} \mathrm{~h}$, respectively, in $9 \mathrm{Cr}$ steel. Since the size as tempered state $r_{0}$ is almost the same in both steels as can be seen in Fig.6, the size difference in the two steels after annealing is attributable to the difference in the rate constant $k$ as the following equation.

$$
r-r_{0}=k t^{1 / 3}
$$

On the other hand, the dependence of the $\mathrm{Z}$ phase size on annealing time is quite different from that of $\mathrm{M}_{23} \mathrm{C}_{6}$ carbide, although the data is only obtained from $10.5 \mathrm{Cr}$ steel, in which the $\mathrm{Z}$ phase is observed relatively in the early stage of annealing. As shown in Fig.6, the coalescence rate of the $\mathrm{Z}$ phase depends on $\mathrm{t}^{1 / 2}$ of annealing time, indicating that the Z-phase coagulates much faster than $\mathrm{M}_{23} \mathrm{C}_{6}$ carbide and that the rate controlling process is interface reaction (interfacial moving). As a result, the size of the Z-phase in $10.5 \mathrm{Cr}$ steel is about $60 \mu \mathrm{m}$ at $1 \times 10^{4} \mathrm{~h}$, the value of which is much smaller than $73 \mu \mathrm{m}$ of $\mathrm{M}_{23} \mathrm{C}_{6}$ carbide at the same annealing time, but it becomes about $110 \mu \mathrm{m}$ at $3 \times 10^{4} \mathrm{~h}$. This is much larger than that of $\mathrm{M}_{23} \mathrm{C}_{6}$ carbide. 
Figure 7 shows TEM microstructures taken from the two steels crept at $650^{\circ} \mathrm{C}$ for $2731 \mathrm{~h}$ in $10.5 \mathrm{Cr}$ steel and for $5289 \mathrm{~h}$ in $9 \mathrm{Cr}$ steel. Comparing the two microstructures, it is obvious that the progress of microstructural evolution in $10.5 \mathrm{Cr}$ is faster than that in $9 \mathrm{Cr}$ steel, even though the crept time of $9 \mathrm{Cr}$ steel is about two times longer than that of $10.5 \mathrm{Cr}$ steel.
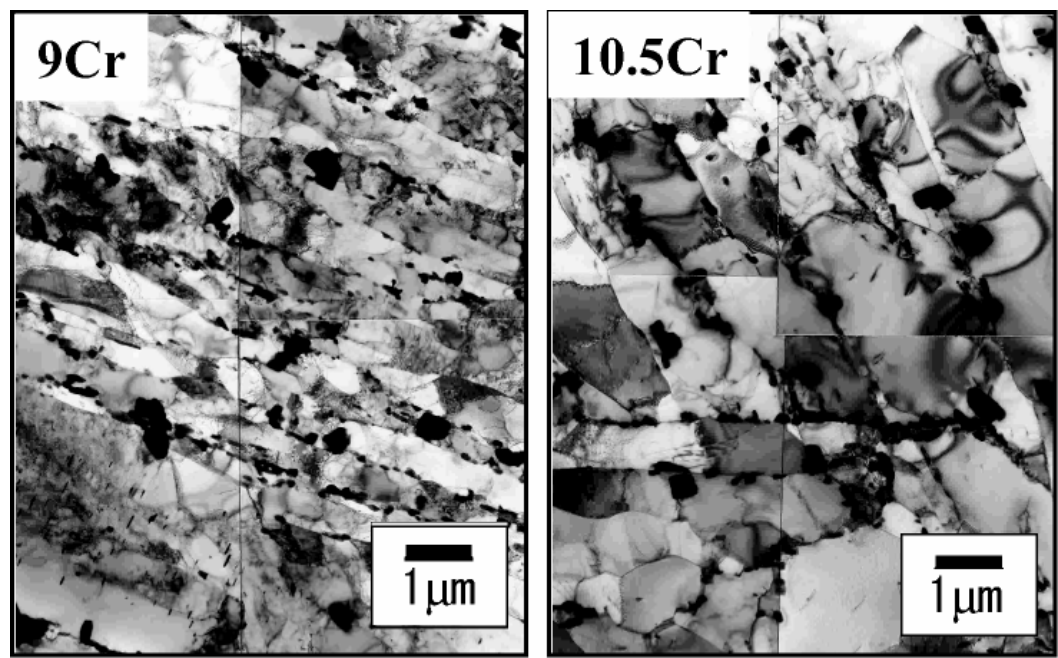

Fig.7 TEM microstructures after $650^{\circ} \mathrm{C}$ creep rupture tests. Rupture times and the stress levels are $5289 \mathrm{~h}$ at $157 \mathrm{MPa}$ in $9 \mathrm{Cr}$ steel and $2731 \mathrm{~h}$ at $118 \mathrm{MPa}$ in $10.5 \mathrm{Cr}$ steel, respectively.

It has been believed that the premature failure occurring in high $\mathrm{Cr}$ heat resistant ferritic steels is due to replacing the fine MX carbonitride by the coarse $\mathrm{Z}$ phase during creep at high temperatures. Also, it is reported that thermodynamic potential for the $\mathrm{Z}$ phase formation increase with increasing $\mathrm{Cr}$ content in high $\mathrm{Cr}$ ferritic steels ${ }^{(7)}$, resulting in occurring the $\mathrm{Z}$ phase formation easily in high $\mathrm{Cr}$ steels. This is consistent with the results obtained in this study. However, the $\mathrm{Z}$ phase formed in the early stage is not so large size, as shown in Fig.6. Furthermore, the size of $\mathrm{M}_{23} \mathrm{C}_{6}$ carbide depends on $\mathrm{Cr}$ content in the steels, i.e., it is smaller in $9 \mathrm{Cr}$ steel than that in $10.5 \mathrm{Cr}$ steel. These facts indicate that not only the $\mathrm{Z}$ phase formation but also the difference in the coalescence rate of $\mathrm{M}_{23} \mathrm{C}_{6}$ carbide between the two steels affects the long term creep strength of the steels. This microstructural difference appears in a long term, and hence it is considered that $\mathrm{Cr}$ diffusivity should be changed by $\mathrm{Cr}$ content in steels, because atomic diffusivity affects the behavior of all precipitates and microstructural evolution. In fact, it is reported that the interdiffusion coefficient becomes lower with increasing up to $12 \mathrm{mass} \% \mathrm{Cr}$ in $\mathrm{Fe}-\mathrm{Cr}$ binary system ${ }^{(8)}$. This difference of diffusivity depending on $\mathrm{Cr}$ content in steels affects every process related to diffusion process in the steels, resulting in the difference in the microstructural evolution between $9 \mathrm{Cr}$ steel and $10.5 \mathrm{Cr}$ steel.

\section{Summary}

In order to make clear the premature failure observed in creep of high $\mathrm{Cr}$ heat resistant steels, the precipitation behavior at $650^{\circ} \mathrm{C}$ of both $\mathrm{M}_{23} \mathrm{C}_{6}$ carbide and the $\mathrm{Z}$ phase was investigated using two kinds of high $\mathrm{Cr}$ heat resistant steels varying only $\mathrm{Cr}$ content. The results are summarized as follows.

(1) The amount of $\mathrm{M}_{23} \mathrm{C}_{6}$ carbide is almost the same in the two steels, but the $\mathrm{Z}$ phase amount in $10.5 \mathrm{Cr}$ steel in annealed specimens is larger than that in $9 \mathrm{Cr}$ steel.

(2) It is observed that the size of $\mathrm{M}_{23} \mathrm{C}_{6}$ carbide in $9.0 \mathrm{Cr}$ steel is much smaller than that in 
$10.5 \mathrm{Cr}$ steel.

(3) The coalescence rate of $\mathrm{M}_{23} \mathrm{C}_{6}$ carbide is found to be proportional to $\mathrm{t}^{1 / 3}$ in both steels, indicating that the rate controlling process for the coalescence of $\mathrm{M}_{23} \mathrm{C}_{6}$ carbide is diffusion. (4) The coalescence rate of the $\mathrm{Z}$ phase measured in the $10.5 \mathrm{Cr}$ steel is proportional to $\mathrm{t}^{1 / 2}$, implying that the rate controlling process for the coalescence of the $\mathrm{Z}$ phase is interfacial reaction (interfacial moving).

(5) These phenomena mentioned above are considered to be one of the reasons for the premature failure observed in $10.5 \mathrm{Cr}$ steel in a long term creep test.

\section{Acknowledgements}

This work was supported in part by the Grant-in-Aid for Scientific Research of Japan Society for the Promotion of Science (JSPS), Japan. Also, a part of this work was supported by The Hibi Research Grant in Japan.

\section{References}

(1) H.Kushima, K.Kimura and F.Abe: "Degradation of Mod.9Cr-1Mo Steel during Long-term Creep Deformation” (in Japanese), Tetsu-to-Hagane, Vol.85, No.11, (1999), pp.841-847.

(2) R.Hashizume, K.Miki, T.Azuma, T.Ishiguro, Y.Murata and M.Morinaga: "Optimization of $\mathrm{Cr}$ Content in High Cr Heat Resistant Steels on the Basis of Long Term Creep Strength", Tetsu-to-Hagane, Vol.88, No.11, (2002), pp.793-800.

(3) K.Miki, T.Azuma, T.Ishiguro, R.Hashizume, Y.Murata and M.Morinaga: "Effect of $\mathrm{Cr}$ Content on the Creep Strength and Microstructural Change in High Cr Heat Resistant Steel", Materials for Advanced Power Engineering 2002, Eds., J.Lecomte-Beckers et al., (2002), pp.1497-1504.

(4) A.Strang and V.Vodarek: " $Z$ phase formation in martensitic $12 \mathrm{CrMoVNb}$ steel", Materials Science and Technology, Vol.12, No.7, (1996), pp.552-556.

(5) D.Brandon and W.D.Kaplan: Microstructural Characterization of Materials, John Wiley and Sons, New York, 1999, p.354.

(6) Y.Murata, M.Morinaga, R.Hashizume, K.Takami, T.Azuma, Y.Tanaka and T.Ishiguro: "Effect of carbon content on the mechanical properties of $10 \mathrm{Cr}-5 \mathrm{~W}$ ferritic steels", Materials Science and Engineering, Vol.A282, (2000), pp.251-261.

(7) H.K.Danielson and J.Hald: "A thermodynamic model of the Z-phase Cr(V,Nb)N", Computer Coupling of Phase Diagram and Thermochemistry, Vo.31, (2007), pp.505-514.

(8) K.Iwashita, K.Yamashita, Y.Murata, M.Morinaga, T.Hara, K.Miki, T.Azuma and R.Hashizume: "Dependence of precipitation behaviour on $\mathrm{Cr}$ content in high $\mathrm{Cr}$ ferritic heat resistant steels and the interdiffusion of Fe-Cr system" (in Japanese), Current Advances in Materials and Processes of Iron and Steel Institute of Japan (CAMP-ISIJ), Vol.23, No.6,(2008), p.1353. 